\title{
ANALISIS SISTEM INFORMASI AKUNTANSI PEMBELIAN BAHAN BAKU SECARA TUNAI GUNA MENINGKATKAN EFEKTIVITAS PENGENDALIAN INTERN PADA PT. DWI MULYO LESTARI MADIUN
}

\author{
Fefi Wuri Ambarwati \\ Isharijadi \\ Pendidikan Akuntansi IKIP PGRI Madiun
}

\begin{abstract}
This study evaluates the raw material purchasing system are applied in PT. Mulyo Dwi Lestari in order to enhance the effectiveness of internal control. The data was collected using interview and observation techniques. The analysis conducted is qualitative descriptive analysis. Based on the research that has been done, researchers can take the conclusion that the implementation of raw material purchasing system in the PT. Mulyo Dwi Lestari not support the effectiveness of internal control. The weaknesses include there isn't form of purchase orders, goods receiving report form is not suitable with the basic principles of design, a dual function in the barn, yet numbered printed form, and never made a sudden inspection of the accounting records company's physical wealth.
\end{abstract}

Keywords: Raw Material Purchasing System, Effectiveness, Internal Control.

\begin{abstract}
ABSTRAK
Penelitian ini bertujuan untuk mengevaluasi sistem pembelian bahan baku secara tunai yang diterapkan di PT. Dwi Mulyo Lestari guna meningkatkan efektivitas pengendalian intern. Pengumpulan data dilakukan dengan menggunakan teknik wawancara dan observasi. Analisis yang dilakukan adalah analisis deskriptif kualitatif. Berdasarkan penelitian yang telah dilakukan, peneliti dapat mengambil simpulan bahwa pelaksanaan sistem pembelian bahan baku secara tunai di PT. Dwi Mulyo Lestari belum mendukung efektivitas pengendalian intern. Adapun kelemahan tersebut antara lain belum ada format formulir memo permintaan pembelian, format formulir laporan penerimaan barang belum sesuai dengan prinsip dasar perancangan formulir, adanya perangkapan fungsi pada bagian gudang, formulir belum bernomor urut tercetak, serta tidak pernah dilakukan pemeriksaan secara mendadak terhadap catatan akuntansi dengan kekayaan fisik perusahaan.
\end{abstract}

Kata Kunci:,Sistem Pembelian Bahan Baku, Efektivitas, Pengendalian Intern.

\section{PENDAHULUAN}

Dalam kegiatan suatu perusahaan tentunya tidak lepas dari kegiatan transaksitransaksi untuk pemenuhan kegiatan perusahaan dalam rangka menghasilkan barang atau jasa yang dijual dipasaran. Untuk menunjang semua kegiatan yang ada tersebut diperlukan adanya transaksi pembelian. Bagi sebagian besar perusahaan, transaksi pembelian merupakan hal utama dalam menjalankan kegiatan produksinya. Salah satunya adalah transaksi yang dilakukan oleh perusahaan untuk memperoleh bahan baku atau bahan mentah untuk diolah menjadi barang jadi.Pembelian digunakan untuk pengadaan barang yang diperlukan. Transaksi pembelian dapat digolongkan menjadi 2 yaitu pembelian lokal dan pembelian impor. Pembelian lokal adalah pembelian dari pemasok dalam negeri sedangkan pembelian impor adalah pembelian dari pemasok luar negeri (Mulyadi, 2008) 
Pada perusahaan manufaktur barang-barang yang dibeli akan diolah menjadi barang yang siap dijual, barang-barang yang diolah tersebut disebut bahan baku. Bahan baku adalah barang-barang yang akan menjadi bagian dari produk jadi yang dengan mudah dapat diikuti biayanya (Baridwan, 2008). Bahan baku merupakan salah satu faktor produksi yang sangat penting. Jika terjadi kekurangan bahan baku yang tersedia dapat mengakibatkan terhambatnya proses produksi. Usaha untuk menyediakan bahan baku yang cukup untuk proses produksi tentu harus melakukan pembelian bahan baku. Pembelian bahan baku memegang peranan yang penting dalam kelancaran produksi. Agar kegiatan operasional perusahaan berjalan dengan efektif dan efisien sehingga dapat memperoleh laba seoptimal mungkin, maka harus memperhatikan penerapan sistem akuntansi yang sesuai dengan kondisi perusahaan sendiri. Bentuk perusahaan beragam, sasaran sistem informasi akuntansi juga beragam, meskipun intinya tetap sama yaitu menyajikan informasi. Suatu perusahaan manufaktur misalnya, akan memerlukan sistem informasi akuntasi yang dapat memberikan informasi mengenai biaya produksi barang yang dibuat dan dijual. Sedangkan perusahaan-perusahaan yang memiliki karateristik khusus misalnya biro iklan, kantor akuntan, asuransi, jasa konstruksi, akan memerlukan sistem informasi akuntansi yang intinya dapat menunjukkan pendapatan kotor, biaya yang dikeluarkan, serta laba bersih yang diperoleh (Widjajanto, 2001).

Sistem akuntansi pembelian bahan baku dirancang untuk menangani masalahmasalah yang berkaitan dengan transaksi pembelian bahan baku yang diperoleh. Masalahmasalah yang sering dihadapi pada perusahaan manufaktur berkaitan dengan pembelian bahan baku adalah kelancaran proses produksi, karena tersedianya bahan baku yang cukup merupakan faktor yang menentukan kelancaran proses produksi maka pembelian bahan baku harus dilakukan secara tepat agar tidak terjadi kelebihan atau kekurangan bahan baku.

Dalam SIA siklus-siklus pemprosesan transaksi salah satunya adalah siklus pengeluaran yaitu kejadian-kejadian yang berkaitan dengan perolehan barang dan jasa dari entitas-entitas lain dan pelunasan kewajiban-kewajiban yang berkaitan (Bodnar dan Hopwood, 2000). Salah satu bagian dari siklus pengeluaran adalah pembelian. Baik pembelian bahan baku untuk jenis perusahaan manufaktur atau pembelian produk untuk jenis perusahaan dagang. Transaksi pembelian melibatkan bagian-bagian seperti bagian gudang (permintaan), pembelian, penerimaan, utang dagang, keuangan dan akuntansi (Mulyadi, 2008). Sistem pembelian mencakup prosedur permintaan pembelian, prosedur permintaan penawaran harga dan pemilihan pemasok, prosedur order pembelian, prosedur penerimaan barang, prosedur pencatatan utang, dan prosedur distribusi pembelian (Mulyadi, 2008). Semua prosedur harus dijalankan secara efektif dan efisien untuk melaksanakan suatu sistem pembelian yang baik.

Sistem akuntansi dalam transaksi pembelian yang baik pada suatu perusahaan sangat berguna sebagai informasi baik untuk manajer sebagai pemakai informasi pihak internal maupun pengguna informasi pihak eksternal. Semakin handal dan akurat informasi yang diperoleh, maka semakin tepat keputusan yang akan dihasilkan. Pada pelaksanaan sistem informasi akuntansi dibutuhkan pengendalian intern. Pengendalian intern bertujuan untuk menjaga integritas informasi akuntansi, melindungi aktiva perusahaan terhadap kecurangan, pemborosan, dan pencurian yang dilakukan oleh pihak di dalam maupun pihak luar perusahaan. Selain itu juga dapat memudahkan pelacakan kesalahan baik yang disengaja ataupun tidak. Agar dapat berjalan efektif, pengendalian intern memerlukan adanya pembagian tanggungjawabnya secara khusus (Widjajanto, 2001).

Pembelian bahan baku memungkinkan terjadinya penyimpangan atau kecurangankecurangan. Dalam sistem akuntansi pembelian bahn baku, dilakukan pemisahan tanggung jawab fungsional secara tegas, sistem wewenamg dan prosedur pencatatan yang baik, serta 
praktik yang sehat. Itu semua merupakan pengendalian dalam sistem akuntansi. Pengendalian dimaksudkan untuk mencegah terjadinya penyimpangan atau kecurangan dalam pembelian bahan baku, seperti kecurangan pencatatan harga maupun kuatitas bahan baku yang dibeli. Oleh karena itu, sistem akuntansi pembelian bahan baku sangat dibutuhkan oleh suatu perusahaan untuk menyediakan catatan yang lengkap mengenai pertanggung jawaban dan perlindungan kekayaan perusahaan.

PT. Dwi Mulyo Lestari merupakan perusahaan yang bergerak di bidang jasa konstruksi. Perusahaan ini dalam memproduksi membutuhkan beberapa bahan baku, yaitu: pasir, batu kali, besi, semen, batu bata, kayu, dan sebagainya. Bahan baku tersebut didapatkan melalui pembelian. Perusahaan melakukan pembelian bahan baku baik secara kredit ataupun secara tunai. Sistem pembelian bahan baku yang diterapkan di PT. Dwi Mulyo Lestari melibatkan bagian-bagian yang terkait. Pelaksanaan sistem akuntansi pembelian bahan baku secara tunai pada PT. Dwi Mulyo Lestari belum sepenuhnya melaksanakan pemisahan fungsi secara jelas.

Dari uraian diatas maka penulis tertarik untuk melakukan penelitian sistem informasi akuntansi pembelian pada PT. Dwi Mulyo Lestari yang sedang berjalan, sehubungan dengan hal tersebut maka penulis mengambil judul "Analisis Sistem Informasi Akuntansi Pembelian Bahan Baku Secara Tunai Guna Meningkatkan Efektivitas Pengendalian Intern Pada PT. Dwi Mulyo Lestari Madiun”.

\section{Tinjauan Pustaka}

Sistem informasi akuntansi adalah "kumpulan sumber daya, seperti manusia dan peralatan, yang dirancang untuk mengubah data keuangan dan data lainnya menjadi informasi. Informasi dikomunikasikan kepada berbagai pihak pengambil keputusan." (Bodnar dan Hopwood, 2003). Menurut Nugroho Widjajanto (2001) sistem informasi akuntansi adalah "susunan berbagai dokumen, alat komunikasi, tenaga pelaksana, dan berbagai laporan yang didesain untuk mentransformasikan data keuangan menjadi informasi keuangan". Berdasarkan pendapat para ahli di atas dapat disimpulkan pengertian sistem informasi akuntansi adalah susunan dari bagian-bagian seperti manusia dan berbagai peralatan yang digunakan untuk memproses data menjadi informasi keuangan yang bermanfaat untuk pengambilan keputusan.

Mulyadi (2008) menyatakan fungsi yang terkait dalam sistem akuntansi pembelian adalah fungsi gudang, fungsi pembelian, fungsi penerimaan dan fungsi akuntansi. Pengertian dari fungsi yang terkait dalam sistem akutansi pembelian adalah sebagai berikut:

a. Fungsi Gudang

Dalam sistem akuntansi pembelian, fungsi gudang bertanggung jawab untuk mengajukan permintaan pembelian dengan posisi persediaan yang ada di gudang dan untuk menyimpan barang yang telah diterima oleh fungsi penerimaan.

b. Fungsi Pembelian

Fungsi pembelian bertanggung jawab untuk memperoleh informasi mengenai harga barang, menentukan pemasok yang dipilih dalam pengadaan barang, dan mengeluarkan order pembelian kepada pemasok yang dipilih.

c. Fungsi Penerimaan

Dalam sistem akuntansi pembelian, fungsi ini bertanggung jawab untuk melakukan pemeriksaan terhadap jenis, mutu, dan kuantitas barang yang diterima dari pemasok guna menentukan dapat atau tidaknya barang tersebut diterima oleh perusahaan.

d. Fungsi Akuntansi 
Fungsi akuntansi yang terkait dalam transaksi pembelian adalah fungsi pencatat utang dan fungsi pencatat persediaan.

Menurut AICPA dalam Baridwan (2002) menjelaskan pengertian pengawasan intern itu meliputi struktur organisasi dan semua cara-cara serta alat-alat yang dikoordinasikan yang digunakan di dalam perusahaan dengan tujuan untuk menjaga keamanan harta milik perusahaan, memeriksa ketelitian dan kebenaran data akuntansi, menunjukan efisiensi di dalam operasi dan membantu menjaga dipatuhinya kebijaksanaan manajemen yang telah ditetapkan lebih dahulu. Menurut Widjajanto (2001) pengendalian intern (internal control) adalah suatu sistem pengendalian yang meliputi struktur organisasi beserta semua metode dan ukuran yang diterapkan dalam perusahaan dengan tujuan untuk:

a. mengamankan aktiva perusahaan,

b. mengecek kecermatan dan ketelitian data akuntansi,

c. meningkatkan efisiensi, dan

d. mendorong agar kebijakan menejemen dipatuhi oleh segenap jajaran organisasi.

Unsur-unsur pokok dalam pengendalian intern (Widjajanto, 2001) adalah: struktur organisasi yang memisahkan tanggung jawab fungsional secara tegas; sistem wewenang dan prosedur pencatatan yang memberikan perlindungan yang cukup terhadap kekayaan, utang, pendapatan, dan biaya; pelaksanaan kerja yang sehat dalam melaksanakan tugas dan fungsi setiap unit organisasi; karyawan yang berkualitas sesuai dengan tanggung jawab yang dipikulnya.

Menurut Mulyadi ( 2008) unsur pengendalian intern yang seharusnya diterapkan pada sistem akuntansi pembelian terdiri dari:

a. Organisasi

1) Fungsi pembelian harus terpisah dari fungsi penerimaan.

2) Fungsi pembelian harus terpisah dari fungsi akuntansi.

3) Fungsi penerimaan harus terpisah dari fungsi penyimpanan barang.

4) Transaksi harus dilaksanakan oleh lebih dari satu orang atau lebih dari satu fungsi.

b. Sistem Otorisasi dan Prosedur Pencatatan

1) Surat permintaan pembelian diotorisasi oleh fungsi gudang, untuk barang yang disimpan dalam gudang, atau oleh kepala fungsi pemakai barang, untuk barang yang langsung dipakai.

2) Surat order pembelian diotorisasi oleh fungsi pembelian atau pejabat yang lebih tinggi.

3) Laporan penerimaan barang diotorisasi oleh fungsi penerimaan.

4) Bukti kas keluar diotorisasi oleh fungsi akuntansi atau pejabat yang lebih tinggi.

5) Pencatatan terjadinya utang didasarkan pada bukti kas keluar yang didukung dengan surat order pembelian, laporan penerimaan barang, dan faktur dari pemasok.

6) Pencatatan ke dalam catatan akuntansi harus dilakukan oleh karyawan yang diberi wewenang untuk itu.

c. Praktik yang Sehat

1) Penggunaan formulir bernomor urut tercetak.

2) Pemasok dipilih berdasarkan jawaban penawaran harga bersaing dari berbagai pemasok.

3) Barang hanya diperiksa dan diterima oleh fungsi penerimaan jika fungsi ini telah menerima tembusan surat order pembelian dari fungsi pembelian. 
4) Fungsi penerimaan melakukan pemeriksaan barang yang diterima dari pemasok dengan cara menghitung dan menginspeksi barang tersebut dan membandingkannya dengan tembusan surat order pembelian.

5) Terdapat pengecekan harga, syarat pembelian, ketelitian perkalian dalam faktur dari pemasok sebelum faktur tersebut diproses untuk dibayar.

6) Catatan yang berfungsi sebagai buku pembantu utang secara periodik direkonsiliasi dengan rekening control utang dalam buku besar.

7) Pembayaran faktur dilakukan sesuai dengan syarat pembayaran guna mencegah hilangnya kesempatan untuk memperoleh potongan tunai.

8) Bukti kas keluar beserta dokumen pendukunganya dicap "lunas" oleh fungsi pengeluaran kas setelah di cek dikirimkan kepada pemasok.

Prinsip-prinsip internal control

a. Diadakan pemisahan fungsi yang jelas untuk pihak-pihak yang:

1) Meminta pembelian.

2) Melakukan pembelian.

3) Menerima barang.

4) Menyimpan barang.

5) Mencatat terjadinya pembelian dan timbulnya utang.

6) Mengeluarkan uang untuk membayar pembelian (utang).

b. Setiap pembelian harus didasarkan pada permintaan pembelian dan dengan harga yang bersaing serta kuantitas yang optimal.

c. Bagian pembelian harus mengikuti pengiriman barang-barang dari penjual untuk memastikan ketepatan waktunya.

d. Barang-barang yang akan diterima apabila sesuai dengan spesifikasi dalam order pembelian.

e. Faktur pembelian diperiksa kebenarannya sebelum disetujui untuk dibayar.

Distribusi debit dari barang-barang atau jasa yang dibeli harus dilakukan dengan benar sehingga laporan-laporan untuk pimpinan datanya dapat dipercaya (Baridwan, 2002).

1. Lingkungan Pengendalian

Lingkungan pengendalian mencerminkan sikap dan tindakan para pemilik dan manajer perusahaan mengenai pentingnya pengendalian intern perusahaan. Efektivitas unsur pengendalian intern sangat ditentukan oleh atmosfer yang diciptakan lingkungan pengendalian.

Menurut Mulyadi (2008) lingkungan pengendalian memilki empat unsur, yaitu:

a. Filosofi dan gaya operasi.

Filosofi adalah seperangkat keyakinan dasar (basic belifs) yang menjadi parameter bagi perusahaan dan karyawannya. Philosophy merupakan apa yang seharusnya dikerjakan dan apa yang seharusnya tidak dikerjakan oleh perusahaan. Sedangkan gaya operasi mencerminkan ide manajer tentang bagaimana operasi suatu kesatuan usaha harus dilaksanakan. Ada manajer yang memilih gaya operasi yang sangat menekankan pentinnya pelaporan keuangan, penyusunan dan penggunaan anggaran sebagai alat pengukur kinerja manajer, dan pencapaian tujuan yang telah dirancangkan dalam anggaran, ada manajer yang tidak demikian. Ada majemen puncak perusahaan yang memilih gaya operasi yang lebih condong pada pemusatan kekuasaan ditangan beberapa gelintir menajer puncak, ada manajer yang memilih gaya operasi yang condong pada desentralisasi kekuasaan ke tangan manajemen menengah dan bawah. 
b. Berfungsinya dewan komisaris dan komite pemeriksaan.

Dewan komisaris adalah wakil pemegang saham dalam perusahaan berbadan hukum perseroan terbatas. Dewan ini berfungsi mengawasi pengelolaan perusahaan yang dilaksanakan oleh manajemen (direksi). Jika dewan komisaris terutama terdiri dari manajemen puncak perusahaan, hubungan antara akuntan publik dengan dewan komisaris tidak ada bedanya dengan hubungan antara akuntan publik dengan manajemen perusahaan. Dalam keadaan ini tidak ada yang independen yang dapat berfungsi sebagai penengah anatar manjemen dengan akuntan publik. Pembentukan komite pemeriksaan ini ditujukan untuk memperkuat independensi akuntan publik yang oleh masyarakat dipercaya menilai kewajaran pertanggungjawaban keuangan yang dilakukan oleh manajemen. Berfungsinya dewan komisaris dan komite pemeriksaan akan menciptakan iklim pengendalian yang baik dalam perusahaan berbentuk perseroan terbatas.

c. Metode pengendalian majemen.

Metode pengendalian manajemen merupakan metode perencanaan dan pengendalian alokasi sumber daya perusahaan dalam mencapai tujuan perusahaan. Perencanaan pengendalian manjemen dilakukan melaui empat tahap, yaitu: (1) penyusunan program (rencana jangka panjang), (2) penyusunan anggaran (rencana jangka pendek), (3) pelaksanaan dan pengukuran, dan (4) pelaporan dan analisis.

d. Kesadaran pengendalian.

Kesadaran pengendalian dapat tercermin dari reaksi yang ditunjukkan oleh manajemen dari berbagai jenjang organisasi atas kelemahan pengendalian yang ditujuk oleh akuntan intern atau akuntan publik. Jika manajemen segera melakukan tindakan koreksi atas temuan kelemahan pengendalian yang dikemukakan oleh akuntan intern atau akuntan publik, hal ini merupakan petunjuk adanya komitmen manajemen terhadap penciptaan lingkungan pengendalian yang baik.

2. Efektivitas Pengendalian Intern

a. Efektivitas Pengendalian Intern

Menurut Mahsun (2006) efektivitas adalah ukuran berhasil tidaknya suatu organisasi mencapai tujuannya. Apabila suatu organisasi berhasil mencapai tujuan, maka organisasi tersebut dikatakan telah berjalan efektif. Hal terpenting yang perlu dicatat adalah bahwa efektivitas tidak menyatakan tentang berapa besar biaya yang dikeluarkan untuk mencapai tujuan tersebut. Biaya boleh jadi melebihi apa yang telah dianggarkan. Efektivitas hanya melihat apakah suatu program atau kegiatan telah mencapai tujuan yang telah ditetapkan. Jadi, pelaksanaan pengendalian intern pada sistem akuntansi pembelian dikatakan efektif apabila kegiatan-kegiatan yang dilakukan pada sistem pembelian bahan baku telah mencapai tujuan dari pada pengendalian intern yang telah ditetapkan.

\section{METODOLOGI PENELITIAN}

\section{Pendekatan dan Jenis Penelitian}

Pendekatan penelitian ini dilakukan dengan menggunakan pendekatan kualitatif. Penelitian kualitatif lebih menekankan analisisnya pada proses penyimpulan deduktif dan induktif serta pada analisis terhadap dinamika hubungan antar fenomena yang diamati, dengan menggunakan logika ilmiah (Wirartha, 2006). Penulis menggunakan pendekatan kualitatif karena permasalahan yang akan dibahas dalam laporan ini tidak berkenaan dengan angka-angka tapi mendeskripsikan, menguraikan, menggambarkan, menganalisis, mengevaluasi serta menyimpulkan tentang penerapan pengendalian intern pada sistem akuntansi pembelian bahan baku secara tunai di PT. Dwi Mulyo Lestari. 


\section{Teknik Pengumpulan Data}

Teknik pengumpulan data yang digunakan dalam penelitian ini adalah wawancara dan observasi. Wawancara adalah proses memperoleh keterangan untuk tujuan penelitian dengan cara tanya jawab, sambil bertatap muka antara si penanya atau pewawancara dengan si penjawab atau responden dengan menggunakan alat yang dinamakan interview guide (Nasir, 2009). Metode ini digunakan untuk mengajukan pertanyaan kepada pihak PT. Observasi adalah study yang disengaja dan sistematis tentang fenomena sosial dan gejalagejala alam dengan jalan pengamatan dan pencatatan. Tujuan observasi atau pengamatan adalah memahami ciri-ciri dan luasnya signifikansi dari interelasi elemen-elemen tingkah laku manusia pada fenomena sosial yang serba kompleks dalam pola-pola tertentu (Wirartha, 2006). Pelaksanaannya metode ini digunakan untuk mengambil dokumendokumen yang dibutuhkan dalam penelitian. Dokumen-dokumen yang diambil dalam penelitian ini berupa, surat permintaan pembelian, surat permintaan penawaran harga, surat order pembelian, laporan penerimaan barang, surat perubahan order, nota pembelian bahan baku, faktur, cek, dan bukti kas keluar.

\section{Teknik Keabsahan Data}

Dalam setiap penelitian, harus diusahakan kemantapan dan kebenarannya, sehingga dalam setiap penelitian harus bisa memilih dan menentukan cara-cara yang tepat untuk bisa mengembangkan validitas data yang diperolehnya. Cara pengumpulan data dengan beragam tekniknya harus benar-benar sesuai dan tepat untuk menggali data yang benarbenar diperlukan dalam penelitiannya. Ketepatan data tersebut tidak hanya tergantung dari ketepatan memilih data dan teknik pengumpulannya, tetapi juga diperlukan teknik pengembangan validitas datanya. Penelitian kualitatif terdapat beberapa cara yang bisa dipilih untuk mengembangkan validitas data penelitian. Cara-cara tersebut antara lain berupa teknik triangulasi sumber. Menurut Patton dalam Moleong (2011) triangulasi dengan sumber berarti membandingkan dan mengecek balik derajat kepercayaan suatu informasi yang diperoleh melalui waktu dan alat yang berbeda dalam penelitian kualitatif. Hal ini dicapai dengan jalan membandingkan hasil pengamatan dengan suatu hasil wawancara dengan sistem pembelian bahan baku secara tunai, serta membandingkan hasil wawancara dengan suatu dokumen yang berkaitan.

\section{Teknik Analisis Data}

Peneliti melakukan analisis data untuk mengukur efektifitas pengendalian intern pada sistem pembelian bahan baku secara tunai di PT. Dwi Mulyo Lestari yang meliputi:

1. Analisis Struktur Organisasi

2. Analisis Sistem Otorisasi dan Prosedur Pencatatan Akuntansi

3. Analisis Praktik yang Sehat

4. Analisis Mutu Karyawan

\section{ANALISIS HASIL DAN PEMBAHASAN}

Permasalahan yang timbul disebabkan oleh faktor intern perusahaan. Lemahnya unsur pengendalian intern yang diterapkan terutama pada sistem pembelian bahan baku secara tunai di PT. Dwi Mulyo Lestari menjadi salah satu penyebab permasalahan yang timbul pada PT. Dwi Mulyo Lestari.

Bukti adanya kelemahan unsur pembelian bahan baku secara tunai yang diterapkan pada PT. Dwi Mulyo Lestari adalah perangkapan fungsi pada bagian gudang, yaitu sebagai fungsi penerimaan dan fungsi penyimpanan (gudang), belum adanya format formulir memo permintaan pembelian, penggunaan formulir dalam sistem pembelian bahan baku tidak bernomor urut tercetak, sebagian formulir tidak dibuat rangkap sebanyak bagian yang terkait dengan prosedur, format formulir laporan penerimaan barang yang telah ada belum 
efektif, serta tidak pernah dilakukan pemeriksaan secara mendadak oleh pimpinan perusahaan terhadap kecocokan catatan akuntansi yang dihasilkan dengan kekayaan fisik perusahaan.

1. Akibat dari Permasalahan

a. Adanya perangkapan fungsi pada bagian gudang yaitu fungsi penerimaan dan penyimpanan barang.

b. Belum adanya format formulir memo permintaan pembelian.

c. Penggunaan formulir yang tidak bernomor urut tercetak.

d. Sebagian formulir tidak dibuat rangkap sebanyak bagian yang terkait dengan prosedur.

e. Tidak pernah dilakukan pemeriksaan secara mendadak oleh pimpinan perusahaan terhadap kecocokan catatan akuntansi yang dihasilkan dengan kekayaan fisik perusahaan.

2. Pembahasan dan Solusi

Struktur organisasi pada PT. Dwi Mulyo Lestari belum tersusun secara efektif karena masih terdapat perangkapan fungsi pada bagian gudang. Dalam sistem pembelian bahan baku secara tunai, fungsi penerimaan dan fungsi penyimpanan barang (gudang) dilakukan oleh bagian gudang. Ketika barang yang dikirim oleh pemasok tiba di perusahaan yang menerima adalah bagian gudang, dimana fungsi penerimaan yang memeriksa barang dari kuantitas maupun kualitasnya atas barang yang telah dipesan oleh perusahaan sedangkan fungsi gudang melakukan penyimpanan atas barang yang diterima oleh fungsi penerimaan, serta melakukan pencatatan atas keluar dan masuknya barang di gudang. Sebaiknya barang yang tiba diperusahaan diterima oleh fungsi penerimaan saja, sehingga tugas dan wewenang dari fungsi penerimaan akan terpisah secara jelas serta benar-benar dilaksanakan oleh orang yang ahli dibidangnya. Apabila fungsi penerimaan dan fungsi penyimpanan (gudang) sama, maka kemungkinan terjadinya kecurangan sangat besar. Fungsi penerimaan ini harus memeriksa kuantitas maupun kualitas dari barang yang telah dipesan dengan cara menghitung dan mengecek barang tersebut dengan membandingkan tembusan surat order pembelian yang diterima dari bagian pembelian yang telah diotorisasi oleh pihak yang berwenang sehingga kecurangan yang akan terjadi dapat dicegah dan informasi yang dihasilkan juga terjamin ketelitian dan keandalannya.

Pada PT. Dwi Mulyo Lestari memo permintaan pembelian diotorisasi oleh bagian koordinator lapangan yang berperan sebagai fungsi pemakai. Memo permintaan pembelian ini, belum dibuat dengan format formulir yang efektif melainkan hanya dicatat pada secarik kertas dan tanpa diarsipkan. Nota pesanan disebut juga dengan surat order pembelian diotorisasi oleh pimpinan perusahaan. Formulir ini sebagai dasar untuk bagian pembelian melakukan pengadaan barang dan hanya dibuat dua rangkap. Dengan adanya otorisasi dari pimpinan perusahaan tersebut maka akan menghindarkan kemungkinan diterimanya barang dan timbulnya kewajiban kepada pihak lain yang tidak dibutuhkan oleh perusahaan. Sedangkan laporan penerimaan barang diotorisasi oleh bagian gudang, namun format dari formulir laporan penerimaan yang telah ada belum efektif. Formulir ini diotorisasi oleh bagian gudang karena bagian gudang yang melaksanakan fungsi penerimaan atas barang yang dikirim dari pemasok berdasarkan surat order pembelian yang diterbitkan bagian pembelian. Selanjutnya fungsi gudang juga mencatat transaksi tersebut dalam kartu stock gudang mengenai terjadinya perubahan kuantitas dari bahan baku yang ada digudang baik yang masuk maupun keluar. Bagian keuangan dapat melakukan 
pencatatan atas terjadinya transaksi pembelian bahan baku secara tunai berdasarkan copy surat order pembelian, copy laporan penerimaan barang serta faktur dari supplier.

Berdasarkan pelaksanaan prosedur pembelian bahan baku secara tunai yang ada di PT. Dwi Mulyo Lestari masih memiliki beberapa kelemahan, maka penulis merekomendasikan rancangan terhadap prosedur sistem pembelian bahan baku yang efektif, yang digambarkan pada bagan alir berikut:

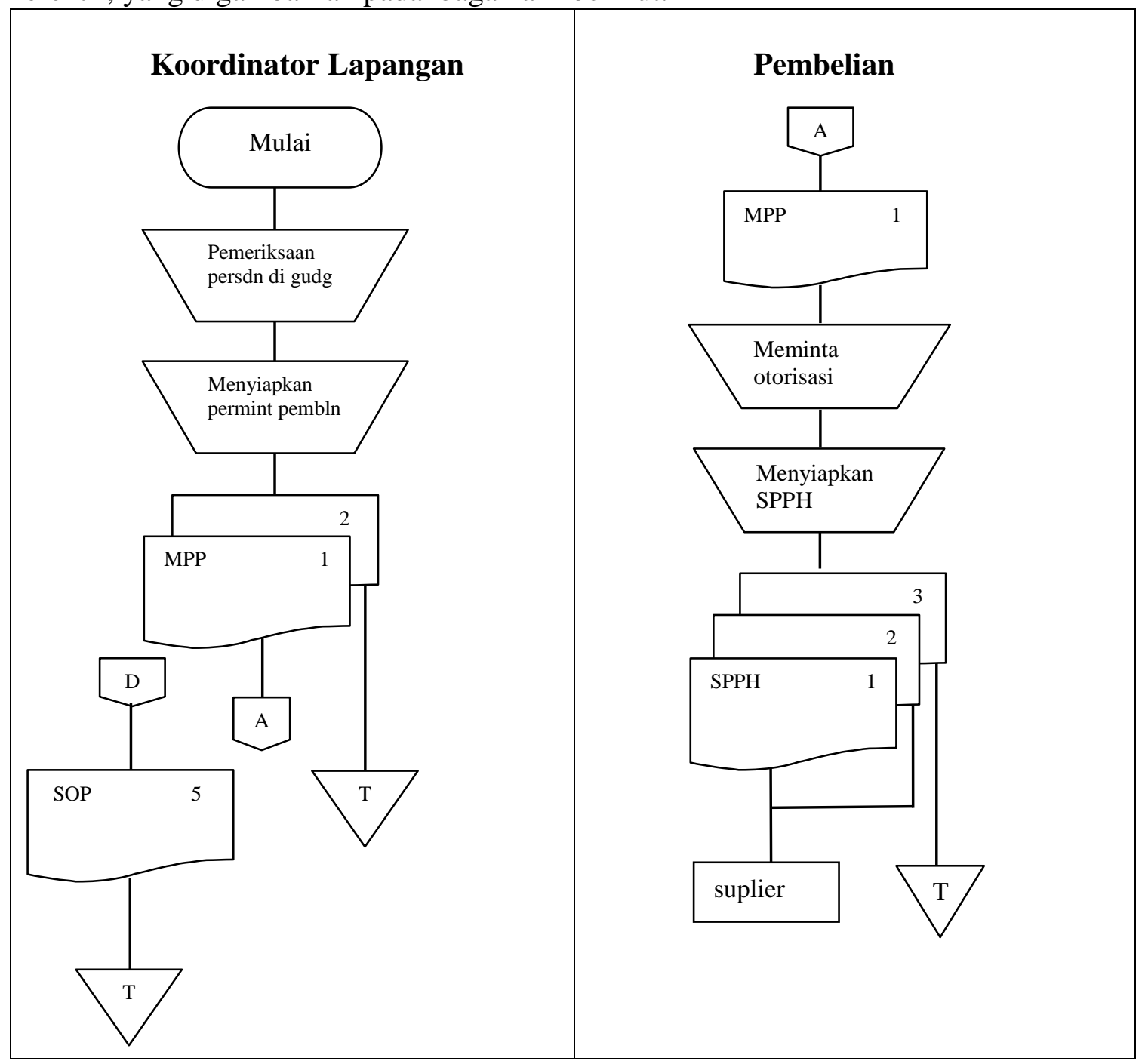

Gambar 1. Rancangan Sistem Pembelian secara Tunai: PT. Dwi Mulyo Lestari

Sumber Data : Hasil Rancangan Diolah Peneliti 


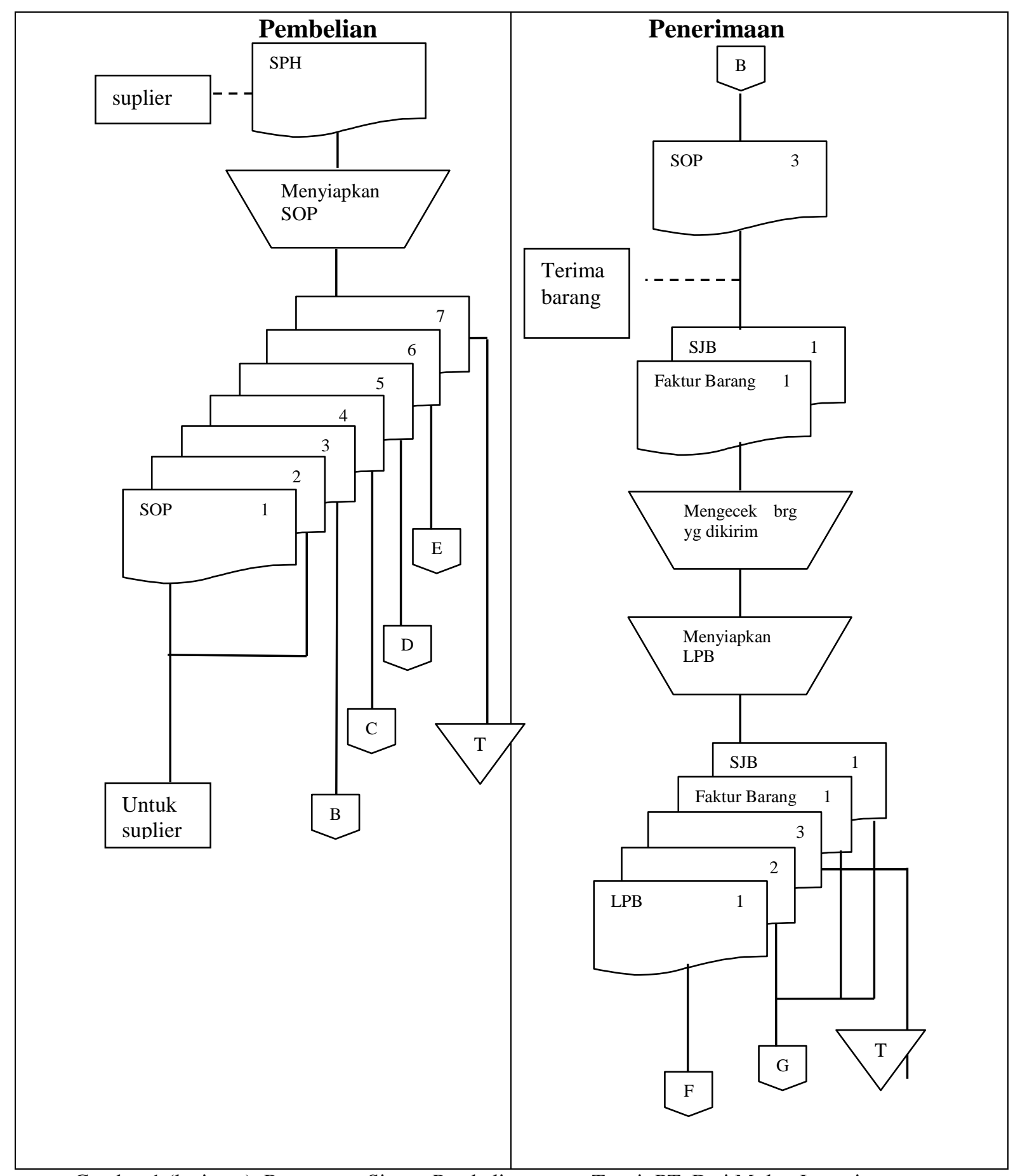

Gambar 1 (lanjutan). Rancangan Sistem Pembelian secara Tunai: PT. Dwi Mulyo Lestari Sumber Data : Hasil Rancangan Diolah Peneliti 


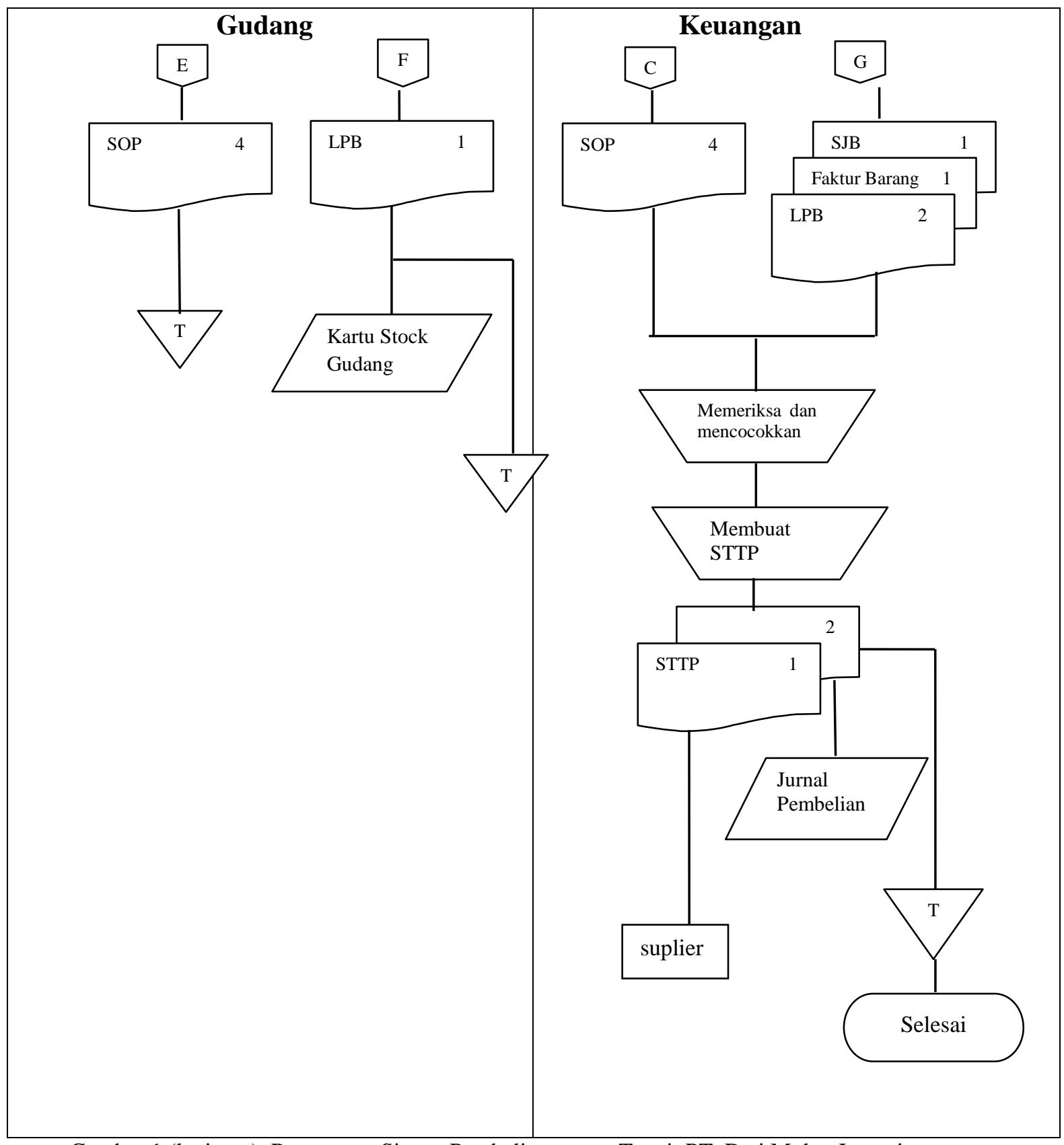

Gambar 1 (lanjutan). Rancangan Sistem Pembelian secara Tunai: PT. Dwi Mulyo Lestari Sumber Data : Hasil Rancangan Diolah Peneliti

\section{KESIMPULAN DAN SARAN}

Berdasarkan penelitian pada PT. Dwi Mulyo Lestari terutama hasil evaluasi pelaksanaan sistem pembelian bahan baku secara tunai dalam kaitannya dengan pengendalian intern apabila dilihat dari unsur sistem pembelian bahan baku secara tunai pada PT. Dwi Mulyo Lestari, maka peneliti dapat mengambil simpulan sebagai berikut:

1. Sistem pembelian bahan baku secara tunai di PT. Dwi Mulyo Lestari pada umumnya telah dilaksanakan sesuai dengan prosedur yang ada ditinjau dari landasan teori, namun masih ada kelemahan yaitu belum ada format formulir memo permintaan pembelian, formulir laporan penerimaan barang belum sesuai dengan prinsip dasar perancangan formulir, formulir belum dibuat rangkap sesuai bagian yang terkait. 
2. Pelaksanaan sistem pembelian bahan baku secara tunai di PT. Dwi Mulyo Lestari belum mendukung efektivitas pengendalian intern. Masih ada beberapa kelemahan yaitu perangkapan fungsi pada bagian gudang, sistem otorisasi dan pencatatannya belum menggunakan formulir yang bernomor urut tercetak, serta tidak pernah dilakukan pemerikasaan secara mendadak terhadap catatan akuntansi dengan kekayaan fisik perusahaan.

3. Perlu dirancang kembali prosedur sistem pembelian bahan baku secara tunai di PT. Dwi Mulyo Lestari agar dapat mendukung efektivitas pengendalian intern.

Dari simpulan diatas, peneliti ingin memberikan saran yang mungkin dapat digunakan oleh PT. Dwi Mulyo Lestari sebagai bahan pertimbangan untuk perbaikan pengendalian intern terhadap sistem pembelian bahan baku secara tunai, antara lain:

1. Sebaiknya menggunakan formulir yang bernomor urut tercetak dan formatnya disesuaikan dengan prinsip dasar perancangan formulir sehingga informasi yang terkait dengan pembelian bahan baku secara tunai dapat terekam dengan baik dan akan mengurangi kegiatan klerikal dari bagian yang terkait dengan prosedur.

2. Sebaiknya upaya meningkatkan pengendalian intern dengan lebih maksimal pada sistem pembelian bahan baku secara tunai melalui pelaksanaan unsur-unsur pengendalian intern yaitu struktur organisasi, sistem otorisasi dan prosedur pencatatan, praktik yang sehat dan mutu karyawan yang sesuai dengan tanggungjawabnya. Sebaiknya PT. Dwi Mulyo Lestari mempertimbangkan untuk merancang kembali sistem pembelian bahan baku secara tunai agar tercipta pengendalian intern yang efektif.

\section{DAFTAR PUSTAKA}

Bodnar, George H dan Hopwood, William S. diterjemahkan Amir Abadi Jusuf dan Rudi M. Tambunan. 2000. Sistem Informasi Akuntansi. Jakarta: Salemba Empat.

Bodnar, George H dan Hopwood, William S. 2003. Sistem Informasi Akuntansi. Jakarta: Indeks.

Wirartha, I Made. 2006. Metodologi Penelitian Sosial Ekonomi. Yogyakarta: Andi.

Nasir, M. 2009. Metode Penelitian. Bogor: Ghalia Indonesia.

Mahsun, Mohamad. 2006. Pengukuran Kinerja Sektor Publik.Yogyakarta: BPFE.

Moleong, Lexy J. 2011. Metodologi Penelitian Kualitatif. Bandung: PT. Remaja Rosdakarya.

Mulyadi. 2008. Sistem Akuntansi. Jakarta: Salemba Empat.

Widjanjanto, Nugroho. 2001. Sistem Informasi Akuntansi. Jakarta: Erlangga.

Baridwan, Zaki. 2002. Sistem Akuntansi Penyusunan Prosedur dan Metode. Yogyakarta: BPFE.

Baridwan, Zaki. 2008. Intermediate Accounting. Yogyakarta: BPFE. 